\title{
Expanding hermeneutics to the world of technology
}

\author{
Jure Zovko ${ }^{1,2}$ \\ Received: 1 December 2019 / Accepted: 14 August 2020 \\ (c) Springer-Verlag London Ltd., part of Springer Nature 2020
}

\begin{abstract}
In this essay, I first analyze the extension of hermeneutical interpretation in the Heideggerian sense to products of contemporary technology which are components of our "lifeworld". Products of technology, such as airplanes, laptops, cellular phones, washing machines, or vacuum cleaners might be compared with what Heidegger calls the "Ready-to-hand" (das Zuhandene) with regard to utilitarian objects such as a hammer, planer, needle and door handle in Being and Time. Our life with our equipment, which represents the "Ready-to-hand" in Heidegger's sense of the word, is determined by temporalization (Zeitigung) which cannot be separated and isolated from the wholeness of things in the world. In the second part of my paper, I explore the positive achievement of material hermeneutics (Don Ihde) with regard to its extension to technoscience and the discussion of how such hermeneutics can contribute to the preservation of our threatened lifeworld, but also to explore the possibilities of how technical inventions, medical innovations could improve our way of life.
\end{abstract}

Keywords Hermeneutics $\cdot$ Being-in-the-world $\cdot$ Ready-to-hand $\cdot$ Technology $\cdot$ Technoscience explanation $\cdot$ Understanding

\section{Introduction}

In the last decades of the twentieth century, hermeneutic philosophy became one of the most influential forms of discourse within the context of the humanities in Continental Europe and Latin America. Italian postmodernist philosopher Gianni Vattimo characterized hermeneutic philosophy as a common language (koinēe of civilized communication in the humanities. ${ }^{1}$ Charles Taylor depicted a human being as a "self-interpreting animal", i.e. as ens hermeneuticum. This definition should explain even more plausibly the differentiation of humans from animals than the classical determination animal rationale. ${ }^{2}$ Richard Rorty foresees a shift today from epistemology to hermeneutics, emphasizing that hermeneutics is "what we get when we are no longer epistemological." ${ }^{3}$ Rorty claimed that hermeneutics is not a substitute for epistemology; nor is it a new theoretical foundation to explain how science or knowledge works, he hopes rather that after the failure of the epistemological approach,

Jure Zovko

jzovko@unizd.hr

Institute for Philosophy Zagreb, Zagreb, Croatia

2 Department of Philosophy, University of Zadar, Zadar, Croatia a "hermeneutic space" will be opened in which tolerance, potential consensus, incommensurability and civility should prevail.

One of the key problems of hermeneutic philosophy is that, under the influence of Wilhelm Dilthey, Martin Heidegger and Hans-Georg Gadamer, it was characterized by a sharp separation and distinction of the humanities from the natural and technological sciences. Unfortunately, Dilthey's distinction between "explanation" (Erklären) and "understanding" (Verstehen) has contributed to the radical bias that all human experience divides naturally into two parts: on the one hand, explanation of the natural world, in which "objective necessity" prevails, and on the other, understanding, in which the inner experience of life dominates. ${ }^{4}$ Dilthey's intention was not to reduce hermeneutics to a description of internal life. He endeavours to show that the universality of understanding forms the creations of human mind. In his influential essay, "The Origin of Hermeneutics", Dilthey defined the task of hermeneutics as follows: "We call the process by which we recognize some inner content from signs received by the senses understanding. [...] The same human spirit speaks to us from stone, marble,

${ }^{1}$ Cf. Vattimo (1989): 38-48; Vattimo /Zabala (2011): 98.

2 Taylor (1985): 15-57.

${ }^{3}$ Rorty (1979): 325, 318.

${ }^{4}$ Cf. Dilthey (1984/1924): 144 sq.: "Die Natur erklären wir, das Seelenleben verstehen wir.". 
musical compositions, gestures, words and writings, from actions, economic arrangements and constitutions, and has to be interpreted." ${ }^{5}$ Gadamer himself accused Dilthey of an unwanted and unacknowledged proximity to Hegel's speculative idealism, claiming that in his later years Dilthey increasingly resembles Hegel rather than Schleiermacher and speaks accordingly of "spirit" (Geist), where he once said "life". Gadamer claims that Dilthey in his late hermeneutics repeated Hegel's conceptual development, despite his criticism of Hegel's monism. ${ }^{6}$

Dilthey's radical separation of the humanities from the methodology of the natural sciences, as presented in his essay "Ideas about a descriptive and dissecting psychology", was widely influential among later thinkers. Both Neo-Kantians (Wilhelm Windelband, Heinrich Ricker) and representatives of the hermeneutical approach in philosophy (Heidegger, Gadamer) insisted on this distinction. British scientist and novelist Charles Percy Snow radicalized this segregation by claiming the natural sciences and the humanities comprise two totally separate cultures, like two galaxies between which there is no communication. According to Snow "the intellectual life of the whole of western society is increasingly being split into two polar groups": literary intellectuals on the one side, and scientists, especially physicists, on the other. "Between the two," he observed "a gulf of mutual incomprehension-sometimes...hostility and dislike, but most of all lack of understanding" had arisen. "They have a curious distorted image of each other. Their attitudes are so different that, even on the level of emotion, they cannot find much common ground". ${ }^{7}$ In a second edition of The Two Cultures, published in 1963, Snow added a new essay in The Two Cultures: A Second Look, where he claimed a third culture would emerge that would mediate between natural sciences and liberal arts. Snow suggested that social scientists could form a "third culture" that will bridge the gap between the natural sciences of the liberal arts. Snow was mistaken when he claimed that social sciences, as a "third culture" would bridge the gap between natural sciences and humanities. In fact, the advent of social sciences actually created a trichotomy in intellectual life.

The best evidence of this is Habermas' philosophy. Habermas claimed in his book Knowledge and Human Interests (Erkenntnis und Interesse 1968) that the natural sciences are characterized by an interest in technical knowledge and by the use of the hypothetic-deductive method. The humanities meanwhile use hermeneutics and are focused on understanding and orientation of human action, while the social

\footnotetext{
5 Dilthey (1976): 248; Dilthey (1924): 319.

${ }^{6}$ Gadamer (1986): 231.

7 Snow (1959): 4.
}

sciences are characterized by an emancipatory interest and apply the so-called critical method. ${ }^{8}$

It is an important achievement of Don Ihde that he abolished the separation of the natural sciences and the humanities introduced by Dilthey and elaborated a material hermeneutics. The reason for this step is that products of the technical sciences are integral components of our lifeworld. Complex questions concerning the application of technical instruments are not only tied to their explanations, but also require our practical understanding of how to use them. Ihde has recognized that people's relationship to their world is shaped by instruments of technical production, that technology has essentially constituted our "image" of the world and as such requires an understanding and a hermeneutic analysis. As traditional hermeneutics has asked about the meaning and significance of the text, material hermeneutics, according to Ihde, should analogously explore the broad spectrum of "instrumental intentions" that characterizes our technological experience, from instrumental "transparency" to "opacity". ${ }^{9}$ Ihde's opinion that the sciences should not merely interpret their content in a positivistic way and that hermeneutics should not be excluded from the technosciences is a good basis for a new orientation of hermeneutics: "The question now becomes one of how a 'new' hermeneutics can be expanded through a focus upon technologies. At the outset, it can be seen that phenomenological epistemology is 'materialist' at least insofar as it centres in actional, perceiving embodiment." ${ }^{10}$ Material hermeneutics should explore topics and phenomena of both the sciences and humanities. The technosciences are hermeneutically structured because they explore the possibility of applying research to practice and test its relevance to the living world.

\section{Heidegger's Hermeneutical treatment of the ready-to-hand}

Heidegger completely transformed traditional hermeneutics by replacing the question of the meaning of the text, which was actually the main theme in hermeneutics from Flacius to Schleiermacher, with the practical question of being, or rather existence (Dasein). According to Heidegger, hermeneutics is no longer a method of understanding a text, work of art, or forms of life, but a means of penetrating the ontology of understanding itself. Heidegger's "fundamental ontology" is conceived as a "hermeneutics of existence" or "being-there" (Dasein) which is primarily concerned with an analysis and understanding of our own being. As

\footnotetext{
${ }^{8}$ Habermas (1968): 143 sq.

${ }^{9}$ Cf. Ihde (1979): 32.

${ }^{10}$ Ihde (1998): 44.
} 
such, Dasein always exists in a world shaped by history and culture, it is a "being-in-the-world" (das In-der-WeltSein). "Being-in-the world" as an "existential" (Existenzial, Heidegger's version of a category of being), for Heidegger means the process by which Dasein (corresponding to the concrete individual human being) explores its potentialities in the world, whereby its understanding is not limited to grasping itself as mere existence, but also how it relates to the implements (Zeug) it utilizes in its actions and behaviour. ${ }^{11}$

The world we cognize and understand by existing and acting in such and such a way and by implementing the things of our experience is a significant, internally connected totality in which individual objects assume their significance and refer to each other through their practical use. Heidegger shows that even the most ordinary "Things" (Zeug) gain a special hermeneutical dimension (a specific constellation of meanings requiring a specific interpretative approach) through their practical use, for example, the hammer, by hammering a nail into a piece of wood-since they disclose the world to us as a "totality of references" (Verweisungszusammenhang). ${ }^{12}$ Heidegger understands this totality of significant references as a "relational system": the professor sits on his wooden chair, at his desk, in his study, preparing for his lectures. The complex structure of the relations of the "entity within-the-world" is already hermeneutically opened up to us by our practical implementation of it: our "Interpretation of the world begins, in the first instance, with some entity within-the-world (das innerweltlich Seiende)."13

When Heidegger claims that cognition is the human's "modus of being as being-in-the-world", this implies our practical, everyday coming to terms with things, our orientation in the world, where the horizon of understanding rests on the understanding of individual entities in the world that do not amount to discrete, unconnected things with no relevance for our understanding of the world in which we find ourselves; they are rather the given that marks us existentially by how we utilize and relate to them.

If, in the sense of Heidegger's hermeneutics, we understand the things of our world as "what is ready-to-hand" (das Zuhandene), those things receive a special relevance: they are components of our "life world". Understanding is a practical "knowledge of how to deal with and utilize things" in their proper context, the "world" in which we discover them. Heidegger's practical concept of "understanding" (Verstehen) is holistic in an entirely different way from theoretical understanding. In this context, Heidegger refers to the practical significance of the Greek word pragmata $(\pi \rho \alpha \dot{\gamma} \gamma \mu \alpha \tau \alpha) .{ }^{14} \mathrm{~A}$ hammer may be an ordinary thing we do not understand, but those who are aware of its practical purpose and use will clearly see in it the hammering of nails, pieces of wood, in house-building, the placement of a horse-shoe, or in the shoemaker's trade. Heidegger's idea of "understanding how to perform something" ("Sich-aufetwas-Verstehen") implies a type of "know-how" belonging to competent, practical dealings with things.

Heidegger can accordingly summarize his thesis of the priority of hermeneutics before the propositional access to things as follows: "Thus assertion cannot disown its ontological origin from an interpretation which understands. The primordial 'as' of an interpretation ( $\dot{\varepsilon} \mu \eta \nu \varepsilon i ́ \alpha)$ which understands circumspectively we call existential-hermeneutical 'as' in distinction from the apophantical 'as' of the statement." ${ }^{\prime 5}$ Heidegger's exploration of the hermeneutical dimension of existential understanding, which is focused on the sense of unity as well as on the coherent totality of meanings, is one of the most important achievements in contemporary philosophy. However, Dasein understands itself mostly in terms of what it is accustomed to take care of and of that "with which it is customarily concerned" $i$. e. what is "Ready-to-hand" (das Zuhandene). ${ }^{16}$

\section{Phronēsis as deliberative form of the being-in-the-world}

Heidegger developed the most important ideas for his hermeneutical approach to reality through his idiosyncratic interpretation of Aristotle's Book VI of Nicomachean Ethics. Heidegger interpreted the keyword of Aristotle's eth-

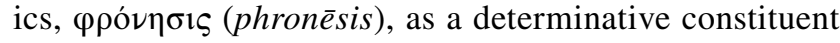
of human existence. The fact that Heidegger applies the most central concept of Aristotelian ethics to the analysis of human "being-there" (Dasein) and existence (Existenz) is understandable because of the structural affinity between the determinations of action and existence. Similar to the agent who does not have the option of refusing to act because of temporal constraints, this applies to the one who exists: she exists and must exist and cannot do otherwise, but execute her existence in time by making concrete decisions along the

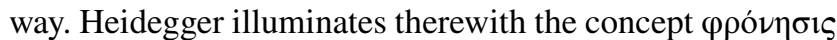
(phronessis) in an unusual and remarkable way. He does not, however, offer a consistent interpretation of Aristotle's ethical theory, but rather diverges from Aristotle in order to

\footnotetext{
${ }^{14}$ Cf. Heidegger (1977a, b): 15.

15 Heidegger (1962): 201; Heidegger (1977a, b): 210.

${ }^{16}$ Heidegger (1962): 283; Heidegger (1977a, b): 319.
}

\footnotetext{
11 Cf. Heidegger (1977a, b): 92.

12 Cf. Heidegger (1977a, b): 94; Heidegger (1962): 99.

${ }^{13}$ Heidegger (1977a, b): 119; Heidegger (1962): 122.
} 
provide his own explication of human action by raising the question as to the meaningful understanding of being.

Heidegger defines phronēsis as the ability to deliberate (überlegen) well and appropriately. The object of deliberation (Überlegung) is factual life itself; its telos is "the being of the one who is deliberating," and its principle the "beingthere" of the human being. ${ }^{17}$ It is not possible to experiment at whim with ethical action, because the ethical knowledge of $\varphi \rho o ́ \nu \eta \sigma i \varsigma$ refers to human existence and because it analyses and understands our being in the context of our life world. The purpose and end of deliberation is the human being itself. Since phronessis relates to the human being in its temporality, which is by nature contingent, ( $\tau$ ó $\dot{\varepsilon} \nu \delta \varepsilon \chi$ ó $\mu \varepsilon \nu 0 \nu$ a' $\lambda \lambda \omega \varsigma$ है $\chi \varepsilon ı$; to endechomenon allos echein), "that which may be thus or otherwise"), and since it must "uncover the concrete singular possibilities of the being of being-there (Daseins)," it is "new every time". ${ }^{18}$

Heidegger interpreted Aristotelian practical wisdom or phronessis in his early writings before Being and Time as care for one's own self and the things in the world that concern us, or are very important for our lives. ${ }^{19}$ In the famous Natorp report (1922), phronēsis was interpreted for the first time as a "caring circumspection" ("fürsorgende Umsicht"), i.e. as dealing with the inner-worldly entities. ${ }^{20} \mathrm{Cir}$ cumspection is further understood as practical knowledge (praktisches Sichauskennen) in the sense of the Aristotelian

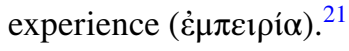

In Being and Time, Heidegger emphasized the concept of "care for one's own existence" (Sorge um das eigene Dasein) as fundamental character and vocation of human beings. Heidegger's understanding of being is based thereby on the concept of care, which in its various variations constitutes an ontologically transcendent structure of being. Being-in-the-world manifests itself as a care for one's own self, and this care implies the obtaining (Besorgen, to provision oneself with) the "things at hand" (das Zuhandene), together with solicitude (Fürsorge) for other people, which Heidegger has defined as "Mit-dasein" (Being-togetherwith). ${ }^{22}$ For Heidegger, therefore, existing means taking care of one's own being, including things (das Zuhandene) that are a matter of "concern" to us (for our survival and our well-being as beings-in-the-world) and the people we deal with. Thus, concern has an aspect of orienting us for the future, which remains open to us. When we "take care" of our existence, we are basically "caring" for the things

\footnotetext{
17 Heidegger (1992): 48.

18 Ibid. p. 135.

19 Cf. Heidegger (2005): 376; Heidegger (2002): 183.

${ }^{20}$ Cf. Heidegger (2005): 376.

21 Ibid. p. 19.

22 Cf. Heidegger (1977a, b): 256; Heidegger (1962): 237.
}

and people that enable us to be-in-the-world. The milieu in which Dasein or human life is carried out is its environment or "surrounding world" (Umwelt). Our existence is therefore not abstract, but always concrete, and determined by reflection on the entire spectrum of things that concern us and are indispensable for our lives. Heidegger calls this existential context of our life world "the totality of references" (Verweisungszusammenhang).

Concern and care for one's soul or being (in Heidegger, Dasein, existence) has been one of the fundamental characteristics of European philosophy since Socrates. Unfortunately, Heidegger did not consider his historical precedents in Being and Time, which is surprising, since this was determined as the purpose of philosophy. In Plato's Early Dialogues (Apol. 36 c; Crit. 47 e; Gorg. 486 e) we can read that Socrates was primarily focused on the concern for one's own soul, which he equated with individual personality. The Socratic technique of argumentative refutation (elenchus) as presented in the early Platonic dialogues is not merely a theoretical method in which wrong views and incorrect definitions are brought to fall, it is also a tool for exercising proper care of one's own soul (epimeleisthai tês psychês; Apol. 29e2), by examination of one's unquestioned assumptions and beliefs. It is therefore identical with self-enquiry and concern for one's own personality (epimeleia heautou; Apol. 29d). The question what constitutes the good life, or "how to live" ( $\pi \tilde{\omega} \varsigma \beta 1 \omega \tau \varepsilon \dot{\alpha}$ v Gorg. $492 \mathrm{~d}$ ), remains in the foreground of the Socratic discussion and ultimately proves to be a type of argumentation (elenchein) that strives for moral clarity and the realization of intrinsic values. If in the Apology it was stated that for Socrates the "unexamined

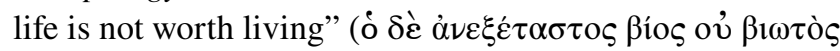
à $\theta \rho \omega ́ \pi \omega ;$ Apol. 38a), it remains to explore which form of life is suited to human beings, and which makes us happy and satisfies us. Elenchus, then, is a process of permanent examination of one's own life with regard to eudaimonia, i. e. how to achieve a good and happy life. The virtue of phronessis plays thereby a key role, as a skill in exercising good judgement for the development of good habits and ultimately for the achievement of excellence of character. Phronessis is reasonable thinking ranging from a judgement of a specific situation to the key question of how to achieve a good and happy life.

The care of oneself was, in Foucault's opinion, a central part of Hellenistic culture from Plato to Seneca, Plutarch and Galen. It was not only the field of philosophy, but also the study of medicine and its myriad of achievements that contributed to establishing the concept of self-care. Philosophy has primarily been concerned with care for the soul of man, while medicine has been a care of the health of the body. ${ }^{23}$

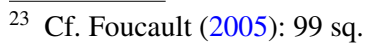


Progress and improvement of medicine depend directly on the development of technology and science. The invention of new drugs, the production of new medical devices, and the improvement of medical technology have increased the quality of medical care.

Care for people's health does not consist only in the treatment of diseases, but is focused on prevention of diseases. Preventive medicine is becoming more and more important because with regard to the most significant illnesses of our time, it is truly the case that 'Prevention is better than cure'. Diseases, such as cancer, which were once considered incurable, if discovered early are often curable. In the case of breast cancer, mammography helps to discover in the early stages of cancer breast, so that it need not lead to terminal disease. Experts believe that colorectal cancer can be prevented by regular check-ups in $75-90 \%$ of all cases. And many infectious diseases can now be brought under control by coordinated programs of vaccination (tetanus, diphtheria, hepatitis B, influenza). Health ministries in European countries usually recommend their citizens to be vaccinated against various infectious diseases before travelling to tropical areas. In the case of the COVID-19 pandemic, it has become clear what apocalyptic proportions the spread of a novel virus can attain, if no vaccination is available. Nevertheless, it has been shown that measures of social distancing, proper hand hygiene, and lockdown measures can help contain the spread of disease and mitigate the global pandemic. The quality of human life has improved due to the progress of medicine, which in this case relies extensively on epidemiology and social medicine. Suffering and pain due to illness or medical intervention can in many cases be alleviated and reduced to a minimum by pharmacological measures. But in the present pandemic, where critical cases are separated from family and loved ones due to the danger of infection, the importance of humane intervention, particularly on the part of front-line medical personnel, has become increasingly visible.

\section{Consideration of the technological threat to our life world}

During the first half of the twentieth century, it was quite common among philosophers not to clarify ethical questions within the framework of rational justification but to regard them as private and subjective convictions and attitudes. Among these are representatives of logical empiricism and followers of existential philosophy (Heidegger, Sartre). This view has prevailed in the field of scientific research, namely that science should be value-free. Modern bioengineering and technology confronts us with a number of difficult moral challenges, in that we can no longer rely on our emotions alone, but when we make ethical decisions we must use our reasoning and arguments. For a long time, the view that science is value-free was accepted in the philosophy of science. Over time, three criteria of scientific research have become established: impartiality, neutrality and autonomy. ${ }^{24}$ The neutrality of the sciences with regard to values is justifiable, insofar as scientific theories contain no value judgements among their logical inferences. ${ }^{25}$ The developmental biologist Lewis Wolpert claims that science in itself and scientific knowledge as such are value-free, without ethical implication. Science tells us how the world is. Dangers and ethical issues only arise according to Wolpert "when science is applied as technology. However, ethical issues can arise in actually doing the scientific research, such as doing experiments on humans or animals, as well as issues related to safety. The problem is the conflation of science and technology." 26 Nevertheless, it must be emphasized that Wolpert's concept of value-free science is in itself an abstract model, because scientists always research with certain motives and intentions, so that the purpose of research usually remains connected with ethical questions and implications. The view that scientific research as a whole can be value-free must, however, be labelled as very dangerous, because it ignores the potential for threats to our environment and the fabric of society posed by novel and unexpected results and their uncontrolled implementation for technological innovations.

To alleviate this threat, I believe it is necessary to implement some form of material hermeneutics as proposed by Ihde and reflective judgement as understood by Kant to study the development of technosciences. The current efforts to reduce emissions of global greenhouse gases have proven ineffective, and global warming continues to increase at a rate that can have terrible consequences for future generations in regards to climate change. A universal hermeneutics in the sense in which Gadamer used it should not remain a problem of linguistic interpretation and a theory of understanding, but ought to also be applied in a concrete and practical sense in cooperation with scientists and experts from every field to resolve the situation regarding the threat to our natural environment, diversity of cultures and social cohesion in a global and international context. Following Heidegger, Don Ihde has endeavoured to rethink the relationship between technology and science, and to address environmental issues and the problem of ethics and the good

\footnotetext{
$\overline{24}$ Cf. Lacey (1999): 2.

25 Dermot Moran (2013: 106) writes on the problem of the concept of "value-free science": "There is an idealised version of pure science that is regularly encountered in the classroom and in academia, but there is also the difficult situation that science is in thrall not just to the latest technology but also, in capitalist societies to certain funding requirements (e.g. major drug companies, military investment, and so on).".

26 Wolpert (2005): 1254.
} 
life in a technical-scientific era. From Ihde's work on material hermeneutics, it becomes apparent that questions raised in the later thought of Heidegger are relevant to the problems mentioned above, and that its relevance should be explored within the context of research and socio-cultural discourse regarding these pressing issues.

Heidegger refers on the close relationship between scientific research and its technological application: "Modern physics, as experimental, is dependent upon technical apparatus and upon the progress in building technological apparatus." ${ }^{27}$ In a conversation with R. Wisser for Zweites Deutsches Fernsehen in 1969, Heidegger made it clear that it was not an antagonism toward technology which led to his considerations, but that he saw the danger of a loss of human self in the uncritical use of technology: "First of all, it has to be said that I am not against technology. I have never spoken against technology, not even about the so-called demonic of technology, but I try to understand the essence of technology". Heidegger continued to express his concern about developments in biotechnology: "[...] so I think of what is developing today as biophysics: that in the foreseeable future we will be in a position to make man in such a way, i.e. to construct purely according to his organic nature the way he is needed." 28 The essence of technology, understood as a framework (Gestell), contains two moments which can become a danger. On the one hand, it poses the danger of human beings becoming themselves only the customer of the technical holdings (Bestand), but at the same time the danger of "over-extending themselves" in the miscalculation of their own position, as if they were the masters of the earth.

Heidegger has plausibly shown how modern technology can serve people in the analysis of "highway bridges". In the "Building Dwelling Thinking" essay, Heidegger provides a remarkable analysis of a contemporary technology that seems to embrace some of the aspects of an authentic artifact: "The highway bridge is tied into the network of longdistance traffic, paced and calculated for maximum yield. Always and ever differently the bridge initiates the lingering and hastening ways of men to and fro ... The bridge gathers, as a passage that crosses, before the divinities-whether we explicitly think of, and visibly give thanks for, their presence, as in the figure of the saint of the bridge, or whether that divine presence is obstructed or even pushed wholly aside." ${ }^{29}$ Hubert Dreyfus and Charles Spinosa explain that this unique passage shows Heidegger accepting that technological things such as highway bridges may allow for a "plurality of communities of focal celebration." ${ }^{30}$ Heidegger

\footnotetext{
$\overline{27}$ Heidegger (1977a, b): 14. Cf. Heidegger (2000): 15.

28 Cf. Wisser (1970); Cf. Heidegger (2000b): 706.

${ }^{29}$ Heidegger (1971): 150. Cf. M. Heidegger (2000a): 155.

30 Dreyfus and Spinosa (1997): 173.
}

has confronted us with the deep problems of development of modern technology. Current problems in the biotechnological sciences are similar to biophysics projects, which Heidegger has harshly criticized. We are now in a state where we as philosophers should be permanently vigilant. The question is whether we are still competent to deal with all possible dangers or to recognize them.

The idea to engineer the human genome for the purpose of improving or enhancing Homo sapiens is like the crossing of the apparently intransgressible boundary, with which a new era of unlimited biotechnological research possibilities with unpredictable consequences should begin. ${ }^{31} \mathrm{We}$ are not yet aware of all the repercussions that will follow from this paradigm-shift from emendation of human moral behaviour to emendation of physical abilities. Scientific and biotechnological research could lead humankind into an irreversible situation where it is no longer possible to return to the status ante quem. In this light, we can no longer insist on the separation of the technological sciences from the human and social sciences, because both are realities of our life world (Lebenswelt). Bruno Latour has beautifully shown how Heidegger's discussion of the world as "Fourfold" (Gestell) can provide the necessary conditions for redefining the position of technology from point of view of its relevance to our living world. This presupposes a complex train of thought that turns the objects of our technical world into things of reflection and matters to which we devote care and concern.

In the context of his critique of technology Heidegger has emphasized as a particularly dangerous trend of science the transformation of biology into biophysics. ${ }^{32}$ This could result in a dangerous turn in the history of the human species that man, like any other technological object, can be produced according to a particular plan or the wishes of the customer. The idea to engineer the human genome for the purpose of improving or enhancing of Homo sapiens has already opened the intense discussion about transhumanism. ${ }^{33} \mathrm{We}$ are not yet aware of all the consequences of this paradigm shift from humanism to transhumanism. Transhumanism could prove to be the greatest danger of modern and future society. I conclude with a famous quote from the German poet Friedrich Hölderlin: "But where danger is, there also grows that which saves" ("Wo aber Gefahr ist, wächst/ Das Rettende auch", Hölderlin, Patmos). ${ }^{34}$ The primary task

\footnotetext{
31 Cf. Wieland (2003): 68. W. Wieland compares this potential step from humanism to posthumanism with the transition across Rubicon. Caesar's crossing of the small foot of Rubicon symbolizes the abolition of the Roman Republic and the beginning of the reign of the Roman emperors.

32 Cf. Interview with R. Wisser in: Heidegger (2000b): 704.

33 Cf. Agar (2004); Agar (2013).

Bostrom and Savulescu (2009): 25-33.

${ }^{34}$ Hölderlin (2000): 426.
} 
of philosophical hermeneutics should be to consider how to contribute to this process of preserving our life world. In his Letter on Humanism, written immediately after the Second World War, Heidegger claimed that the meaning of the word "humanism" should be redefined: "That requires that we first experience the essence of the human being more primordially [anfänglicher]; but it also demands that we show to what extent this essence in its own way becomes destinal." ${ }^{35} \mathrm{It}$ remains questionable whether the new dimension of humanity can be understood from the perspective of the question of being, i.e. from the ontological difference. Heidegger referred to the fatal consequences of the transformation of biology to "biophysics", but unfortunately did not offer any solutions.

\section{Discussion: expanding hermeneutics to the world of technology}

Heidegger's idea of "understanding how to do something" ("Sich-auf-etwas-Verstehen") implies a type of "know-how" of competent, practical dealing with things. Accordingly, Heidegger can summarize his thesis of the priority of the hermeneutic before the apophantic access to things as follows: "Thus assertion cannot disown its ontological origin from an interpretation which understands. The primordial 'as' of an interpretation ( $\dot{\rho} \mu \eta \nu \varepsilon i ́ \alpha)$ which understands circumspectively we call existential-hermeneutical 'as' in distinction from the the apophantical 'as' of the statement."36 The hermeneutic state of having been discovered (Entdecktheit) which characterizes the things that concern us, Heidegger refers to as "totality of applications" or "purposes" (Bewandtnisganzheit). This totality presupposes the world of technological products, which are also used and applied in our life world. In my opinion, it is necessary to extend hermeneutical reflection to the products of contemporary technology, insofar as they are also components of our life world. Some products of modern high technology, such as mobile phones and laptops, have become an indispensable part of our life world. They have acquired the function of Heidegger's "availability" (das Zuhandene = "Ready-tohand") in our lives. In other ways we are bound in our lives to household appliances, electronic devices, automobiles, airplanes, ships and trains. They are all at our disposal, i.e. "ready-to-hand" in a Heideggerian sense. Even objects that we do not use ourselves are often indirectly part of our life world, for example, equipment for security checks, X-ray machines, instruments for complex surgical operations. We may never operate any of these devices ourselves, but

\footnotetext{
35 Heidegger (1998): 263; Heidegger (1976a, b): 345.

${ }^{36}$ Heidegger (1977a, b): p. 210; Heidegger (1962): p. 201.
}

they can nevertheless be of specific relevance to our lives. Our life with things which are the "ready-to-hand" in Heidegger's sense of the word, is determined by temporalization (Zeitigung) which cannot be separated and isolated from the wholeness of things. Our conscious life proves to be the "web of understanding" of the practical handling of things. If the fundamental characteristic of hermeneutic understanding in Being and Time is its projective, future-oriented structure (Entwurf als Verstehen), the activity of understanding by means of care for and implementation of the things of our experience can also be applied to the world of technological products, which are also a form of "availability" (das Zuhandene = "Ready-to-hand") in the contemporary society. Heidegger's concept of "being projected" (Entwurf) concerns also things (Dinge) in the world in their mutual relation. The main problem raised by Heidegger's hermeneutical analysis of the "Ready-to-hand" is that it does not consider the question of morality and the moral evaluation of its application.

In this sense, the distinction made by Bruno Latour following Heidegger's late philosophy is very important, namely the differentiation between things that concern us and the objects we are indifferent to, as seeming insignificant for our life in the world: "A thing is, in one sense, an object out there and, in another sense, an issue very much in there, at any rate, a gathering." "The same word thing," notes Latour, "designates matters of fact and matters of concern."37 The key hermeneutical question for Latour is thereby how to transform "matters of fact into highly complex, historically situated, richly diverse matters of concern." 38 Although Bruno Latour ostensibly criticizes Heidegger's conception of technology, his interpretation of technology is determined from the point of view of Heidegger's hermeneutic treatment of the "Ready-to-hand" (Das Zuhandene) from Being and Time, or "Things" (Ding), as depicted in Heidegger's late work. According to Latour, Heidegger misunderstood the quintessence of the modern technology when he claimed that technology is "unique, insuperable, omnipresent, superior, a monster born in our midst which has already devoured its unwitting midwives". ${ }^{39}$ In contrast to Heidegger's epigones, who have declared the weakness of Heidegger's thinking with regard to the critique of modern technologies to be his strength, the noteworthy characteristic of Latour's philosophy is that he extends Heidegger's hermeneutical approach to the "Read-to-hand" to the world of technology and its products. Latour is correct when he does not restrict Heidegger's explanation of the gathering dimension of language and the "thing" to rural phenomena as jug, peasant shoes,

\footnotetext{
37 Latour (2004): 233.

38 Ibid., p. 237.

39 Latour (1999): 176
} 
"Schwarzwaldhof", village bridge, but rather extends these ideas to the objects of technology and science. In an ironic tone, Latour, referring to Heidegger's quotation of Heraclitus, claims that gods are also present in a hydroelectric plant on the Rhine River, in Adidas' sports shoes, in microscopes and mobile phones, as well as in a farmhouse in the Black Forest, wooden shoes and some particularly touching examples from Hölderlin's poetry. ${ }^{40}$

Heidegger's influence on Latour is evident in his assertion that "Thinking is hand-work". Everything that is "in one's hands" Latour designates as "inscriptions." ${ }^{\text {"1 }}$ Bruno Latour has this quote from Heidegger's lectures What does Thinking Mean $?^{42}$ (Was heißt Denken?), where Heidegger has made sharp distinctions between science and thinking. Science is burdened by theory, and has a primarily calculative character. Thinking is distinguished by its practical reference; it is a bodily event, a "hand-work". Thinking is oriented mostly towards what we have to do, and to the "Ready-to-hand" (das Zuhandene), which enables us to carry out the "task at hand". In his critique of the dominance of modern technology, Heidegger simultaneously refers to the original meaning of the word "techn $\vec{e}$ " which was intended to imply a reorientation with regard to our living with technology: "Tغ́ $\chi \nu \eta$ : to be well-versed in the handling and i.e. to know its area the accessibility (Zuhandenheit) $\alpha \lambda \eta \theta \varepsilon v \dot{\varepsilon} u \nu "{ }^{43}$ We read the classics of philosophy — and in my opinion Heidegger is one of them-with the intention of reproducing what is always valid in their philosophical works and critically examining their shortcomings. Heidegger's reflections on the Greek concept of "techne" can be taken as an opportunity not only to analyse modern technology from a negative point of view, as Heidegger has done, but also to fathom the relevance of technology for our life world. Therefore, the central idea of this contribution is to hermeneutically discuss the products of the most modern technology as part of being in the world as "the totality of references" (Verweisungszusammenhang).

Hermeneutic reflection, in other words, if it is going to remain a relevant approach to our technological society, ought to incorporate products and achievements of modern technology as an integral part of our concept of a "life world". Our everyday "being-in-the-world" would be unthinkable without the sophisticated products of technology familiar to us today, from cell phones to the worldwide web and cloud computing. Our understanding of the contextuality and interrelationships of the things which determine

\footnotetext{
${ }^{40}$ Latour (1993): 66.

${ }^{41}$ Cf. Latour (1986): 20.

42 transl. of title, Marie-Élise Zovko.

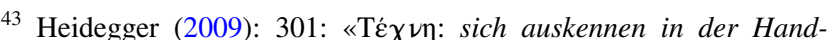
habung und d. h. deren Bereich (der Zuhandenheit) kennen-, $\alpha \dot{\alpha} \eta \eta \varepsilon \dot{\varepsilon \varepsilon \iota . " .}$
}

our "being-in-the world" today is not made possible only or even primarily by the hammers and nails, handles and doors which Heidegger has analyzed in detail in Being and Time, but first and foremost by laptops and cellphones, e-mails and the Internet.

Our contingent life depends furthermore heavily on the complex management of trade and shipping, above all for the supply and distribution of basic necessities, as well as on the help of advanced medicine and pharmacy. Many diseases from which people died thirty years ago are generally curable today, due to the rapid development of medicine and technology. But we are also confronted with the resurfacing of diseases previously thought to have been eradicated, due to a growing lack of confidence in vaccinations (due to a great extent on ignorance, misinformation, i.e. "fake news"), and also to the appearance of strains of antibiotic-resistant bacteria—due to an overestimation of our own human capabilities and miscalculation of the effects of indiscriminate use of antibiotics. This is particularly important for the world of technology, which is to be analyzed in all its diversity. The development of the most modern equipment also implies the ability to understand it, especially in its practical use. Modern technology has enriched our lives in many ways, made them easier, enabled us to be satisfied and happy.

Although modern technological development has changed and improved our lives in many ways, it has also opened the Pandora's Box of potential technological disasters with unpredictable consequences. With the modernization of technology, we are confronted with threats in a way that we have never been before. We have to come to terms with the risks of different types of vulnerability and, if possible, analyze and consider the technological threat more effectively and thoroughly. This is also the most important reason why we should integrate hermeneutic reflection into the philosophy of technology.

If we consider the different forms of technology as an essential segment of our experience and our life world, then technology is no longer "value-free" but world-immanent, and we need to pay close attention to the implications and interactions that different forms of technical development and application may have in our lives. An ethically motivated and morally determined reason should guide our life practice, and guide the experience that is shaped by technology.

Our life world is also the world of technological instruments, which have also character of Zuhandensein (the Ready-to-hand) because they are available to us in our practical life.

An outstanding achievement of Ihde's material hermeneutics is that he has extended the application of hermeneutical interpretation of the Ready-to-hand to the practice of technoscience. In the emergence of modern science, mathematization was used as a model for theory; in modern 
times, the practical relevance of science is emphasized (Gaston Bachelard, Bruno Latour, Gilbert Hottois, Don Ihde). With regard to imaging as an example of "the technological embodiment of science," Ihde says, it is "not some set of 'pictures,' it is the praxical, instrumental Zuhanden of that which reveals a world." In the same way, with regard to the application of phenomenology and hermeneutics to the situation of our planet and lifeworld today, as Ihde demonstrates:

Insofar as science is not merely some set of mathematized theory, but is embodied as a technoscience which materially relates to a world, and insofar as the Earth is a perceivable planet, and then, insofar as our measurements are critically reconstructed through instrumentally constitutive praxis, then phenomenologists can detect the possible greenhouse effect. ${ }^{44}$

The disappearance of practice and the "theoretical" approach to reality was one of the main characteristics of the philosophy of science in the twentieth century. Relating to this Heidegger claims: "It would be easy to suggest that merely looking at entities is something which emerges when concern holds back from any kind of manipulation. What is decisive in the 'emergence' of the theoretical attitude would then lie in the disappearance of praxis.. ${ }^{45}$

Early critics of the theory-ladenness of philosophy of science, Norwood R. Hanson, Stephen Toulmin, Thomas S. Kuhn, Paul Feyerabend have taken up their ideas against the theoretization of experimental practice from late Wittgenstein. Wittgenstein decided against making the method of science the paradigm of philosophical argumentation, because such a method leads philosophers into complete darkness. The reason for his taking this view is that Wittgenstein was convinced at the time that philosophy is "purely descriptive," and is not justified in "reducing" "anything to anything" (for example, physical data to generalized theoretical statements). ${ }^{46}$ Following Wittgenstein, NR Hanson already denied the universal validity of the hypotheticaldeductive method and recommended a "retroductive" explanation of data, a form of Peircean abduction which claims to improve on the $\mathrm{H}-\mathrm{D}$ method remaining closer to the physical data in its attempt at providing an explanation, whereas Wittgenstein says philosophers shouldnot explain anything. ${ }^{47}$

\footnotetext{
${ }^{44}$ Ihde (1998): 60.

45 Heidegger (1977a, b): 473; Heidegger (1962): 409.

${ }^{46}$ Cf. Wittgenstein (1958): 18.

47 Cf. Hanson (1958): 70: „There is also something wrong with the H-D [hypothetico-deductive] account, however. If it were construed as an account of physical practice it would be misleading. Physicists do not start from hypotheses; they start from data. By the time a law has been fixed into an H-D system, really original physical thinking is over.".
}

The main problem of the methodology of the prominent representatives of the theory of science before the practical turn was that its subtly elaborated logical argumentation had almost nothing to do with the practice of empirical sciences such as physics, chemistry, biology, physiology, technoscience, and as such was not at all applicable in scientific research. Material hermeneutics and technoculture have taught us in the meantime that objects of research could also be things that concern us as proper knowledge and understanding of them is indispensable for maintaining the integrity of our natural and life world. A main aim of hermeneutical philosophy in our time should be then to help us to interpret and understand in an enlightened and reasonable way difficult and controversial issues in contemporary scientific research, from research regarding the physical universe as a whole and its workings, to environmental and demographic science, epidemiology, life sciences, medicine, chemistry and all the advances in technology to which they are constantly being applied in new and innovative ways.

Albert Borgmann analyses the comfortable life of modern man from the standpoint of the current state of technological progress, using the example of central heating. ${ }^{48}$ The boiler, thermostat, pipes and radiators of a central heating system provide heat in winter and make a pleasant living environment possible. Active human intervention is needed only in case of system failure. But heat in the dwelling can also be provided by the built-in chimney, which requires human intervention, such as collecting wood, chopping wood, feeding and tending the fire, poking and cleaning the hearth. The second method of heating is more in keeping with the spirit (and perhaps somewhat antiquated view) of Heidegger's philosophy, but for pragmatic reasons both forms of life should be analyzed from the point of view of our "being-in-theworld". Today, it may be seen as a luxury to sit comfortably in front of the chimney and listen to the crackle of fire, while large parts of the population in industrial countries are uninvolved on a daily basis in the actual process of heating their homes, except to program their thermostats and another large portion of the world's population lacks the means to heat their living quarters or must rely on much more basic means. Borgmann believes that the development of modern technology has resulted in intensification and expansion of the passivity of life, promoting consumerism, rather than the meaningful contextuality of implementation characteristic of the use of tools in an earlier age ${ }^{49}$ The products of contemporary technology have in modern society achieved the structure of mere presence (Vorhandenheit) in Heidegger's sense, whereas their manual relevance has been lost. In my opinion, a difference must be drawn between

\footnotetext{
48 Borgmann (1987): 43 sq.

49 Cf. Borgmann (1987): 52.
} 
earlier products of technology which still involved a kind of active physical engagement like the automobile as it was originally produced to be driven and manipulated by the driver and later advances from remote controls to robotics, which are implementing artificial intelligence to an ever degree, including all our "smart" devices, "smart" homes and even self-driving cars and planes. Yet there is in the kind of indirect control of these devices and the interaction with virtual reality which they require and encourage a new kind of "readiness-to-hand" (Zuhandenheit) which is gradually replacing that of our former mode of interaction with physical tools and objects of our mundane environment. This "readiness-to-hand" is as real in its virtual way as any physical tool ever was-and fully determinate of our life world in all its complexity. Loss of one's mobile phone or laptop on a train or plane means that we have also lost communication with others, even with our own lives.

Don Ihde has applied Heidegger's analysis of the hermeneutic and practical reference to the context of the tool as an opportunity to explore man's relationship to technical products that are part of our being in the world. Technological artifacts, such as the microscope, thermometer and manometer resemble Heidegger's of things which are "ready-tohand" (zuhanden) and exhibit also a bodily contextuality. The physical dimension is expressed through dance, figure skating, athletic sports disciplines such as rhythmic gymnastics with various props, pommel horse and trampoline. In such cases, the "Zuhandene" is bound to the human body in a special way. Ihde explains how technological artifacts like these convey in their human-technology relationships how people experience and interpret the world. ${ }^{50}$ Ihde has emphasized the practical dimension of Heidegger's tool analysis and convincingly demonstrated that Heidegger's practical knowledge is not cognitive, but "tacit" and "bodily" ${ }^{51}$ With reference to Merleau-Ponty's Phenomenology of corporality, Don Ihde has discussed Heidegger's hermeneutic tool analysis from the point of bodily activity. In Ihde's example of the use of the cane by blind people, the cane appears as a special form of the Ready-to-hand that opens experience of and communication with the physical world to the blind. Only when you try to put yourself in the inner state of a blind person and settle into his life can you understand what it means to orient oneself independently in the world without the use of sight. The cane permits access to that world which we take for granted. Braille, the alphabet used by the blind, functions in an analogous way, by providing access to the world of education and culture. The ethical dimension of the Ready-to-hand becomes clear from these examples, since

\footnotetext{
50 Cf. Ihde (1979): 103 sq. Cf. Ihde (2009).

51 Ihde (2009): 33.
}

accessibility in this respect is not only a question of justice, but also of respect for the dignity of human beings.

Karl Polanyi has characterized Heidegger's phenomenological uncovering of entities in the world as a model of personal tacit knowledge. ${ }^{52}$ The epistemological implications of Heidegger's concept of "being in the world" is primarily shown in the reflective orientation towards producendum, the comprehending use of inner-worldly entities, manifests itself as a subtle form of tacit knowledge in which formation of our life world is analyzed and investigated. Heidegger therefore says that "this 'knowledge' however, does not mean that it has discovered some fact, but that it holds itself in an existential possibility". ${ }^{53}$ In this context, it is desirable to explore whether Heidegger's analysis of being in the world as a theory of tacit knowledge could undermine the representational conception of knowledge of modern epistemology, which remains blind to the forms of non-propositional knowledge. As the disengaged picture of modern epistemology is traced back to the committed actions in our daily lives, the recognition of non-representational knowledge raises the question of the other foundation of epistemology.

Different prosthetic implants, such as coronary stent, cardiac pacemaker, cochlear implant and the other artificial devices which correct or replace the defective functions or missing body parts are especially important for sick and handicapped persons. Robotic legs and arms have now become part of our everyday lives.

Heidegger's idea of "understanding how to do something" ("Sich-auf-etwas-Verstehen") is a practical knowledge of the context of interrelated tools, i.e. a way of uncovering of entities (Entdecktheit des Seienden). In the Marburg lectures Logic. Von der Wahrheit (1925/1926), when Heidegger explores what it means when a thing is understood "from the point of view of what it serves" "von dem her, wozu es diene" ${ }^{54}$ we are dealing with hermeneutical handling or with the practical understanding of something. The discussion of everyday use of tools appears in a number of variations in Heidegger's early writings. We can use this hermeneutic framework as a starting point for criticism of his late philosophy. Instead of Heidegger's glorification of the "things" (Dinge) that belong to the life forms of the past (jug, country lane, farm in the Black Forest), I think it is necessary to consider this type of hermeneutic analysis within the context of contemporary life and as a means of interpreting products of technology which are components of our daily lives, to try to better understand in what sense they make our lives

\footnotetext{
52 Cf. Polanyi's preface to the Torchbook Edition of Personal Knowledge, Polanyi (1964): $\mathrm{x}-\mathrm{xi}$.

${ }^{53}$ Cf. Heidegger (1977a, b): 445.

${ }^{54}$ Heidegger (1976a, b): 146.
} 
easier, but whether and how they may unnecessarily burden us in promoting a consumerist lifestyle.

\section{Conclusion}

With regard to the impending dangers that could be caused by modern science and technology, it is plausible that hermeneutical reflection does not aim only at an interpretation and explanation of existing forms of artistic and cultural creation. It seeks reflective answers to both the challenges of the contemporary age and the complex issues pertaining to modern societies. The task of hermeneutics should also include a complex understanding and judgement of a concrete situation as well as the ways to cope with the issue of application of the universal to the particular. In the words of Hans-Georg Gadamer, hermeneutical reflection poses the questions that relate to the whole of human world experience and the life practice: "It asks (to put it in Kantian terms): How is understanding possible?"55 Hermeneutics will preserve its universal determination of Dasein, in Heidegger's sense of the word, if it applies the universal dimension of understanding to the analysis of science and technology as they are both involved in our lives or determine our life world. The understanding as the mode of being of Dasein itself presupposes the comprehension of scientific and technical products as far as they are a part of our life world and our existence.

With regard to Gadamer's hermeneutics, Don Ihde is right when he pleads for a step in the direction of material hermeneutics to explore the products of technoscience with regard to their relevance for our life world:

It is the step away from generalizations about technology uberhaupt and a step into the examination of technologies in their particularities. It is the step away from a high altitude or transcendental perspective and an appreciation of the multidimensionality of technologies as material cultures within a lifeworld. ${ }^{56}$

Hermeneutics cannot be restricted to language and life forms alone, as is the case with Gadamer, but should also reflect and explore human life in the context of the technoscientific challenge. Patrick A. Heelan and Jay Schulkin have convincingly showed that already with Heidegger's hermeneutical approach to the world in the encounter with inner-worldly things a new form of interpretation was discovered whose meaning is "cultural praxis-laden" rather than theory-laden. ${ }^{57}$

\footnotetext{
55 Gadamer (2013): p. xxvii; Gadamer (1993): 439.

56 Ihde (2009): 22.

${ }^{57}$ Heelan/Schulkin (1998): 285.
}

Very problematic are Heidegger's formulations from the Black Notebooks that "Sciences' are, like technology and as techniques, necessarily international", an international way of thinking does not exist at all according to Heidegger's judgement, thinking is for him "necessarily a fated dwelling in a singular homeland and singular people." (Denken ist "notwendig ein geschickliches Wohnen in einziger Heimat und einzigem Volk). ${ }^{58}$ If critical thinking is to deal with the challenges of modern technology and science and find answers to existing threats, it must go beyond national and parochial framework conditions. Hermeneutic philosophy should deal critically with the challenges of modern technoscience and take existing threats seriously. Its universality should be shown by the fact that it goes beyond national and state frameworks because we as human beings participate in a common biosphere. At the same time, hermeneutics should show openness to the plurality of cultures and life forms, so that it does not remain on the abstract level, because as human beings we belong to different traditions and in practice try to be humane in different ways.

The rapid development of scientific research and technological world domination has unfortunately led our society as a whole into such an extreme situation, that human beings cannot come to terms with the difficult issues we face without taking recourse to basic ethical norms. Human beings today live under the constant threat of an ecological world catastrophe that could result in the uninhabitability of the earth and the extinction of humanity. We are still far from overseeing all the possible and shocking consequences of genetic engineering of living beings, including human beings. The accountability for human action under the conditions of the modern scientific and technological development in the digital society by no means dispenses with normative ethical justification. Without these basic ethical norms, the human individual would entirely lose her orientation in modern society and have no starting point for cultivating her ethical attitude and faculty of judgement. Consequently, it is necessary to redefine the Aristotelian concept of phronessis

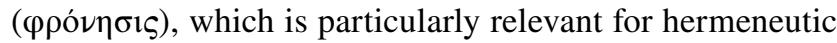
reflection. Accordingly, Gadamer has defined phronēsis as "reasonability" that guides our praxis and life form. Praxis, as a key-concept in Gadamer's late philosophy, denotes "self-conduct and action in solidarity", whereby solidarity is the "decisive condition for all societal rationality". 59

\footnotetext{
58 Cf. Heidegger (2015): 60. Cf. my criticism of Heidegger's Black Notebooks: Jure Zovko, "Hass als Existenzial? Kritische Bemerkungen zu Heideggers Schwarzen Heften" in: Langthaler, Rudolf; Hofer, Michael (Hrsg.) Liebe und Hass: Perspektiven aus Philosophie, Religion und Literatur (Wiener Jahrbuch für Philosophie) (Deutsch) Paperback - 9. July 2019 Wien: new academic press 2019. (99) 99-117.

59 Gadamer (1987): 228.
} 
Acknowledgements The publication of this article was made possible through the funding of the Croatian Science Foundation as part of my research project "Relevance of Hermeneutic Judgement". I thank my wife, Marie-Élise Zovko, as ever, for her corrections and helpful suggestions for improvement of the paper. I would also like to thank Albert Borgmann for critical remarks and advice. My special thanks go to Arun Tripathi, for his critical remarks and suggestions.

\section{References}

Agar N (2004) Liberal eugenics: in defence of human enhancement. Blackwell, Oxford

Agar N (2013) Truly human enhancement: a philosophical defense of limits. MIT Press, Cambridge

Borgmann A (1987) Technology and the character of contemporary life: a philosophical inquiry. University of Chicago Press, Chicago

Bostrom N, Savulescu J (2009) Human enhancement. Oxford University Press, Oxford

Dilthey W (1976) The development of hermeneutics. In: Rickmann HP (ed) Selected writings. Cambridge University Press, Cambridge, $p$ 248

Dilthey W (1984/1924) Ideen über eine beschreibende und zergliedernde Psychologie. Die geistige Welt: Einleitung in die Philosophie des Lebens. Erste Hälfte: Abhandlungen zur Grundlegung der Geisteswissenschaften, Gesammelte Schriften vol. 5, Teubne, Stuttgartr

Dreyus HL, Spinosa C (1997) Highway bridges and feasts: Heidegger and Borgmann on how to affirm technology. Cont Philos Rev 30:159178. https://doi.org/10.1023/A:1004299524653

Foucault M (2005) The hermeneutics of the subject. Lectures at the College de France 1981-1982. Palgrave Macmillan, New York

Gadamer HG (1986) Hermeneutik I: Wahrheit und Methode: Grundzüge einer philosophischen Hermeneutik. Gesammelte Werke vol. 1. Mohr, Tübingen

Gadamer HG (1987) Über die Möglichkeit einer philosophischen Ethik. In: Gesammelte Werke, vol 4. Mohr, Tübingen

Gadamer HG (1993) Hermeneutik II: wahrheit und methode: ergänzungen. Mohr, Tübingen

Gadamer HG (2013) Truth and method. Translation revised by Joel Weinsheimer and Donald G. Marshall

Habermas J (1968) Erkenntnis und interesse. Suhrkamp, Frankfurt

Hanson NR (1958) Patterns of discovery: an inquiry into the conceptual foundations of science $\square$. Cambridge University Press, Cambridge

Heelan PH, Schulkin J (1998) Hermeneutical philosophy and pragmatism: a philosophy of science. Synthese 115:269-302. https://doi. org/10.1023/A:1005032631417

Heidegger M (1962) Being and time translated by John Macquarrie and Edward Robinson. Blackwall, Oxford

Heidegger M (1971) Poetry language thought. Translation and introduction by Albert Hofstadter. Harper Row, New York

Heidegger M (1976a) Logik. Die Frage nach der Wahrheit. Gesamtausgabe, vol. 21. Klostermann, Frankfurt

Heidegger M (1976b) Wegmarken. Gesamtausgabe vol. 9. Klostermann, Frankfurt

Heidegger M (1977a) Sein und Zeit. Gesamtausgabe vol. 2. Klostermann, Frankfurt

Heidegger M (1977b) The question concerning technology and other essays. Translated and with an introduction by William Lovitt. Harper \& Row, New York

Heidegger M (1992) Platon: Sophistes. Gesamtausgabe vol 19. Klostermann, Frankfurt

Heidegger M (1998) Pathmarks. Cambridge University Press, Cambridge

Heidegger M (2000b) Reden und Andere Zeugnisse eines Lebensweges. Gesamtausgabe, vol 16. Klostermann, Frankfurt
Heidegger M (2002) Grundbegriffe der Aristotelischen Philosophie Gesamtausgabe, vol 18. Klostermann, Frankfurt

Heidegger M (2005) Phänomenologische Interpretationen ausgewählter Abhandlungen des Aristoteles zur Ontologie und Logik. Gesamtausgabe vol 62. Klostermann, Frankfurt

Heidegger M (2009) Leitgedanken zur Entstehung der Metaphysik, der neuzeitlichen Wissenschaft und der modernen Technik. Gesamtausgabe vol 76. Klostermann, Frankfurt

Heidegger M (2015) Anmerkungen I-V (Schwarze Hefte 1942-1948), Gesamtasugabe, vol I97. Klostermann, Frankfurt

Hölderlin, F (2000) Patmos. In: Sämtliche Werke, Frankfurter Ausgabe, Patmos, Druckfassung 1803, Frankfurt am Main/Basel

Ihde D (1979) Technics and praxis: a philosophy of technology (Boston studies in the philosophy and history of science). D. Reidel, Dordrecht

Ihde D (1998) Expanding hermeneutics: visualism in science (studies in phenomenology and existential philosophy). Northwestern University Press, Evanston

Ihde D (2009) Postphenomenology and technoscience the Peking University lectures. SUNY Press, Albany

Heidegger M (2000a) Vorträge und Aufsätze. Gesamtausgabe, vol 7. Klostermann, Frankfurt am Main

Lacey H (1999) Is science value free. Values and Scientific Understanding. Routledge, London

Latour B (1986) Visualisation and cognition: drawing things together. In: Kuklick H (ed) Knowledge and society studies in the sociology of culture past and present, vol 6. Jai Press, Greenwich, pp 1-40

Latour B (1993) We Have Never Been Modern. Translated by Catherine Porter. Harvard University Press, Cambridge

Latour B (1999) Pandora's Hope. Essays on the reality of science Studies. Harvard University Press, Cambridge

Latour B (2004) Why has critique run out of steam? From matters of fact to matters of concern. Crit Inquiry 30(2):225-248. https://doi. org/10.1086/421123

Moran D (2013) Science, technology and preservation of the life-world. Eur Rev 21(S1):S100-S108

Polanyi K (1964) Preface to the torchbook edition. In personal knowledge. Harper and Row, New York

Rorty R (1979) Philosophy and the mirror of nature. Princeton University Press, Princeton, pp 318-325

Snow CP (1959) The two cultures and the scientific revolution. Cambridge University Press, London

Taylor C (1985) Philosophy and the human sciences. Cambridge University Press, Cambridge, pp 15-57

Vattimo G (1989) Etica della interpretazione. Rosenberg \& Sellier, Torino, pp 38-48

Vattimo G, Zabala S (2011) Hermeneutic communism: from Heidegger to Marx. Columbia University Press, New York, p 98

Wieland W (2003) Bioethik als Herausforderung. University Press, Bonn

Wisser R (1970) Martin Heidegger in conversation. Arnold-Heinemann, New Delhi

Wittgenstein L (1958) The blue and brown books. Basil Blackwell, Oxford

Wolpert L (2005) The Medawar lecture 1998: is science dangerous? Philos Trans R Soc Lond B Biological Sciences 360(1458):1253-1258

Zhenhua Y (2010) Being-in-the-World in a Polanyian Perspective. In: Margitay T (ed) Knowing and being: perspectives on the philosophy of Michael Polanyi. Cambridge Scholars Publishing, Cambridge

Publisher's Note Springer Nature remains neutral with regard to jurisdictional claims in published maps and institutional affiliations. 